\title{
COMPARISON of TSC-2018 and TSC-2007 REGULATIONS for KONYA in TERMS of EQUIVALENT EARTHQUAKE LOAD METHOD
}

\author{
${ }^{1}$ Mustafa KOÇER ${ }^{(\mathbb{D})}$, ${ }^{2}$ Mehmet UZUN ${ }^{(\mathbb{D})}$, ${ }^{3}$ Mustafa Tolga ÇÖĞÜRCÜ (iD \\ ${ }^{1}$ Konya Technical University, Engineering anf Natural Sciences Faculty, Civil Engineering, Konya, TURKEY \\ ${ }^{2}$ Karamanoglu Mehmetbey University, Engineering Faculty, Civil Engineering, Karaman, TURKEY \\ ${ }^{1}$ mkocer@ktun.edu.tr, ${ }^{2}$ mehmetuzun@kmu.edu.tr, ${ }^{3}$ mtcogurcu@ktun.edu.tr
}

(Geliş/Received: 10.08.2020; Kabul/Accepted in Revised Form: 14.01.2021)

\begin{abstract}
Earthquake motion is a complex movement that is difficult to understand. It is extremely important to understand and apply the earthquake movement correctly in order to affect the structure. There are three different methods in the literature for the application and calculation of the earthquake effect to the building. These methods are Equivalent Earthquake Load, Mode Combination and Analysis in Time History. Equivalent earthquake load method comes to the fore due to its ease of application and clarity. In the new earthquake regulation that entered into force in 2019, radical changes were made in the earthquake map used in the Equivalent Earthquake Load method. In this study, two building models with 3 floors and 9 floors were created and Equivalent Earthquake Load analysis was made according to TSC2007 and TSC-2018 conditions. Results have been compared with each other.
\end{abstract}

Keywords: Reinforced concrete, equivalent seismic load, TSC-2007, TSC-2018

\section{TSC-2018 ve TSC-2007 Yönetmeliklerinin Eşdeğer Deprem Yükü Yöntemi Açısından Konya Özelinde Kıyaslanması}

ÖZ: Deprem hareketi karmaşık anlaşılması zor bir harekettir. Deprem hareketinin yapıya etki ettirilebilmesi için doğru bir şekilde anlaşılarak uygulanması son derece önemlidir. Deprem etkisinin yapıya uygulanması ve hesaplanması için literatürde üç farklı yöntem bulunmaktadır. Bu yöntemler Eşdeğer Deprem Yükü, Mod Birleştirme ve Zaman Tanım Alanında Analiz yöntemleridir. Uygulama kolaylığı ve anlaşılmasının kolay olması Eşdeğer deprem Yükü yöntemini ön plana çıkarmaktadır. Türkiye'de 2019 yılında yürürlüğe giren yeni deprem yönetmeliği ile birlikte Eşdeğer Deprem Yükü yönteminde köklü değişiklikler yapılmıştır. Bu çalışmada 3 katlı ve 9 katlı iki bina modeli oluşturularak TSC-2007 ve TSC-2018 şartlarına göre Eşdeğer Deprem Yükü analizi yapılmıştır. Sonuçlar birbiriyle karşılaştırılmıştır.

Anahtar Kelimeler: Betonarme, eşdeğer deprem yükü, TDY-2007, TBDY-2018

\section{INTRODUCTION}

During the design of structures, dead loads and live loads can be calculated with high accuracy with certain statistics and mathematical calculations. However, the calculation of dynamic loads such as earthquake and wind, which are expected to affect the structures, is a very complex issue. The effect of the earthquake on the structure varies with parameters such as fault characteristics, ground condition and behavior of the structure. Especially the mistakes made during the building design increase the destructive effect of the earthquake (Keskin and Bozdogan, 2018). Since our country is a country in the earthquake zone, accurate calculation of earthquake load is an important study subject. There are generally three different methods in the calculation of earthquake motion. These methods are Equivalent Earthquake Load, Mode Combination and Time History Analysis. 
A new earthquake regulation was published in our country in 2018. Turkey Earthquake Building Regulations (TSC-2018) is made with fundamental changes in many aspects. While the earthquake hazard class of 46 provinces was decreased in the regulation, the earthquake hazard class of 6 provinces was increased. Furthermore, according to the previous regulations TSC-2007, while $43 \%$ of the population of Turkey was taking placed in the highest region of the threat of earthquakes, this ratio was reduced to $27 \%$ in TSC-2018 (Basaran, 2018).

Radical changes were made regarding the Equivalent Earthquake Load Method (EDY) with the new regulation. Building Height Classes (BYS), Strength Redundancy Coefficient (D), design spectral acceleration coefficient (SDS) for short period region, design spectral acceleration coefficient (SD1) for 1.0 second period, changes in ground classes, definition of effective section stiffness in linear analysis and removing the classification of earthquake zones, etc. are some of them.

While many studies with Equivalent Earthquake Load Method are available in the literature, there are limited studies on examining the differences of TSC-2007 and TSC-2018 regulations. Demir and Donmez calculated the earthquake load affecting different structures with the same plan geometries in Z1, Z2, Z3 and Z4 ground classes, and with the Equivalent Earthquake Load Method according to TSC2007. Based on the results obtained have been viewed torsional irregularity in the structure (Demir and Donmez, 2008). Kumbasaroglu and Celik calculated the earthquake load that a historic masonry building can be exposed to using the Equivalent Earthquake Load Method. They examined the linear performance of the structure exposed to earthquake load (Kumbasaroglu and Celik, 2019). Ucar and Merter produced spectrum curves to be used for Equivalent Earthquake Load Method and Mode Combination Method from real earthquake records. For the Time History Analysis Method, they used the acceleration records of the same earthquake. They created 5, 8 and 10-storey reinforced concrete building models and compared the results for three different earthquake calculation methods (Ucar and Merter, 2009). Basaran analyzed two different buildings with 5 and 10 floors using the equivalent Earthquake Load Method given in TSC-2007 and TSC-2018 regulations and compared the results (Basaran, 2018). Balun et al. compared the standard earthquake spectrum given in TSC-2018 with the base shear forces obtained according to the simplified design rules defined in section 17 (Balun et al., 2020). Ozer and Bahadir have made an interactive analysis of a 13-storey building on a rigid basement in Z3 according to TSC-2007 and ZD ground class according to TSC-2018 (Ozer and Yuksel, 2020). Song et al., estimated the equivalent earthquake load parameters in the study. (Song et al., 2018). Dogangun and Livaoglu compared the methods of Equivalent Earthquake Load, Mode Combination and Time History Analysis in their studies (Dogangun and Livaoglu, 2006). Tezcan and Alhan made the earthquake load calculations for the building models with torsional irregularities using the Equivalent Earthquake Load method and dynamic analysis methods (Tezcan and Alhan, 2001). Humar and Mahgoub calculated the earthquake force to be used in the design according to the Canadian earthquake code (NBCC-2005) using the Equivalent Earthquake Load Method (Humar and Mahgoub, 2003).

In this study, three-layer and 9-layer is formed on two different structural models in ETABS program (ETABS, 2020). Building models have been analyzed according to the Equivalent Earthquake Load Method given in TSC-2007 and TSC-2018. The results obtained were compared. The differences between TSC-2007 and TSC-2018 codes have been examined in terms of equivalent earthquake load.

\section{MATERIAL AND METHOD}

Two different models of 3 floors and 9 floors were created within the scope of the study. The 3storey building model is given in Figure 1. 


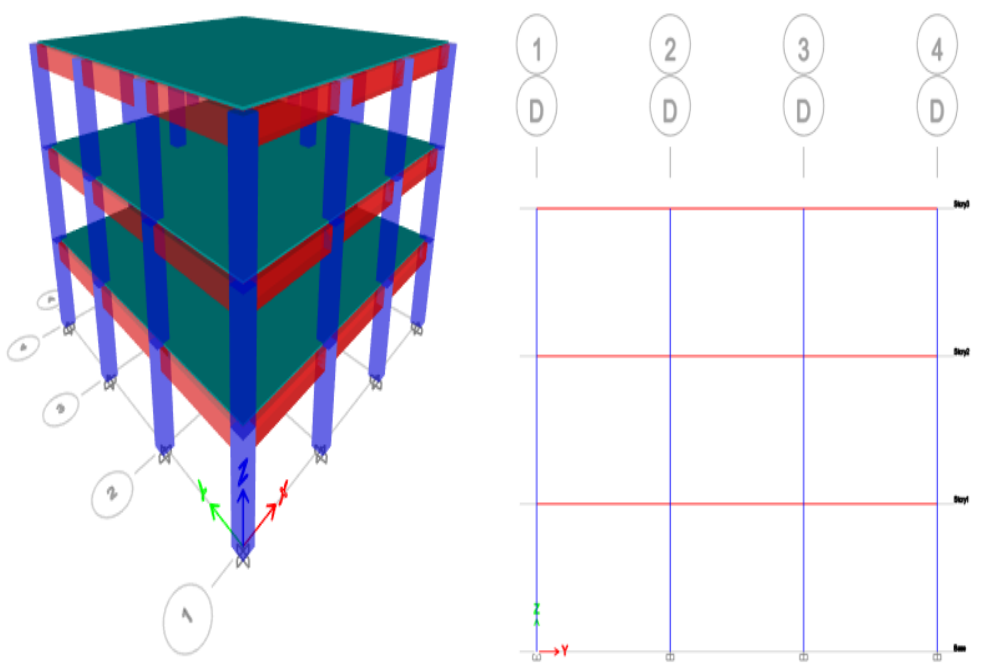

Figure 1. 3-storey building model

The 9-storey building model is given in Figure 2.
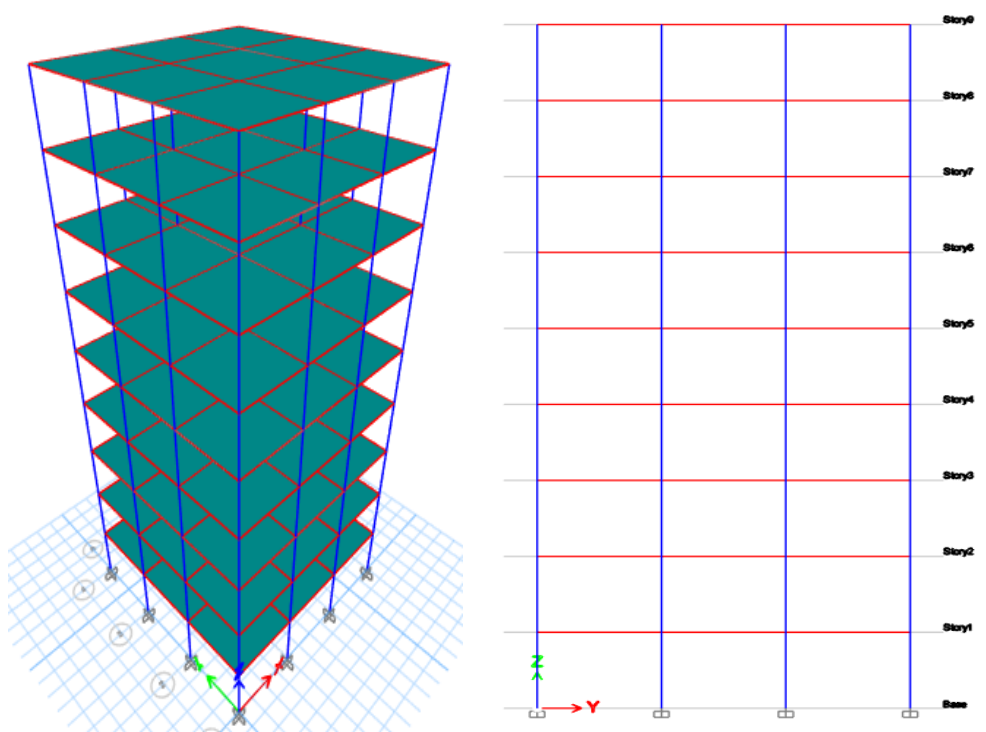

Figure 2. 9-storey building model

The parameters used during the creation of the buildings are given in Table 1 . The parameters given in the Table 1 have been selected by taking into account the minimum requirements in the codes. 
Table 1. Parameters used in creating the model

\begin{tabular}{cccc}
\hline No & Description & 3-storey & 9-storey \\
\hline $\mathbf{1}$ & Number of floors & 3 & 9 \\
$\mathbf{2}$ & Plan dimensions & $12 \mathrm{~m}^{*} 12 \mathrm{~m}$ & $12 \mathrm{~m}^{*} 12 \mathrm{~m}$ \\
$\mathbf{3}$ & Floor thickness & $15 \mathrm{~cm}$ & $15 \mathrm{~cm}$ \\
$\mathbf{4}$ & Beam dimensions & $30 \mathrm{~cm}^{*} 60 \mathrm{~cm}$ & $30 \mathrm{~cm}^{*} 60 \mathrm{~cm}$ \\
$\mathbf{5}$ & Column dimensions & $50 \mathrm{~cm}^{*} 50 \mathrm{~cm}$ & $50 \mathrm{~cm}{ }^{*} 50 \mathrm{~cm}$ \\
$\mathbf{6}$ & Concrete and Steel grade & $30 \mathrm{MPa} / \mathrm{B} 420 \mathrm{C}$ & $30 \mathrm{MPa} / \mathrm{B} 420 \mathrm{C}$ \\
& & Pavement+Coating 0,2 & Pavement+Coating $0,2 \mathrm{t} / \mathrm{m}^{2}$, \\
$\mathbf{8}$ & Floor loads & $\mathrm{t} / \mathrm{m}^{2}$, & Live Load $0,2 \mathrm{t} / \mathrm{m}^{2}$ \\
$\mathbf{9}$ & Live Load $0,2 \mathrm{t} / \mathrm{m}^{2}$ & $0,25 \mathrm{t} / \mathrm{m}^{2}$ \\
$\mathbf{1 1}$ & Building importance factor & $0,25 \mathrm{t} / \mathrm{m}^{2}$ & 1 \\
$\mathbf{1 2}$ & Ground Class & 1 & $\mathrm{Z} 4, \mathrm{ZD}$ \\
$\mathbf{1 3}$ & Building behavior & $\mathrm{Z} 4, \mathrm{ZD}$ & 8 \\
\hline
\end{tabular}

The design spectrum curve defined in the TSC-2007 regulation is given in Figure 3.

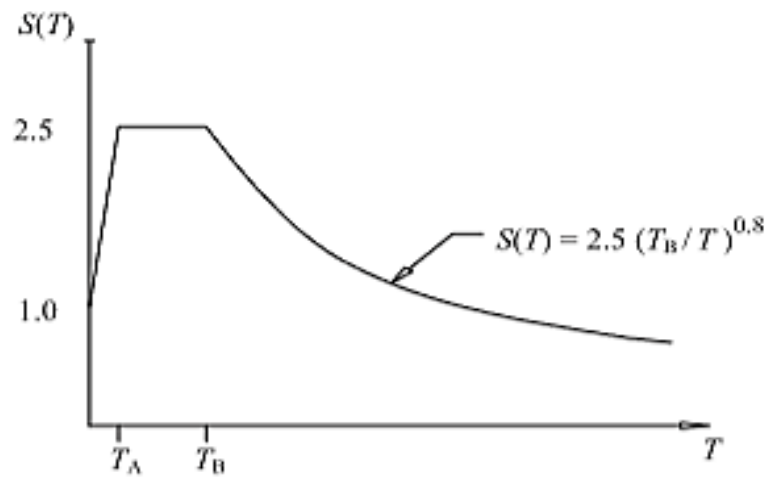

Figure 3.TSC-2007 design spectrum curve (Turkish Seismic Code (TSC-2007) (2007) Specifications for buildings to be built in seismic areas., 2007)

The formulas given in Figure 3 to calculate the spectrum coefficient in three different regions are defined in (1), (2) and (3):

$$
\begin{array}{ll}
S(T)=1+1.5 \frac{T}{T_{A}} & \left(0 \leq T \leq T_{A}\right) \\
S(T)=2.5 & \left(T_{A}<T<T_{B}\right) \\
S(T)=2.5\left(\frac{T_{B}}{T}\right)^{0.8} & \left(T_{B}<T\right)
\end{array}
$$

Here, $\mathrm{S}(\mathrm{T}), \mathrm{T}, \mathrm{T}_{\mathrm{A}}$ and $\mathrm{T}_{\mathrm{B}}$ represent the spectrum coefficient, natural vibration period and spectrum characteristic periods, respectively. Soil characteristic periods are defined in Table 2 depending on local soil classes. 
Table 2. Soil characteristic periods (Turkish Seismic Code (TSC-2007) (2007) Specifications for buildings to be built in seismic areas., 2007)

\begin{tabular}{ccc}
\hline Local Soil Class & $\boldsymbol{T}_{\boldsymbol{A}}(\mathbf{s})$ & $\boldsymbol{T}_{\boldsymbol{B}}(\mathbf{s})$ \\
\hline Z1 & 0.10 & 0.30 \\
Z2 & 0.15 & 0.40 \\
Z3 & 0.15 & 0.60 \\
Z4 & 0.20 & 0.90 \\
\hline
\end{tabular}

The spectral acceleration coefficient is calculated with formula (4), with the help of the design spectrum coefficient.

$$
A(T)=A_{0} I S(T)
$$

Here, $A(T), A_{0}$ and I represent the spectral acceleration coefficient, effective ground acceleration coefficient and building importance coefficient, respectively.

The effective ground acceleration coefficient is classified according to earthquake zones in Table 3.

Table 3. Effective ground acceleration coefficient (Turkish Seismic Code (TSC-2007) (2007) Specifications for buildings to be built in seismic areas., 2007)

\begin{tabular}{cc}
\hline Earthquake Zone & $\boldsymbol{A}_{\mathbf{0}}$ \\
\hline $\mathbf{1}$ & 0.40 \\
$\mathbf{2}$ & 0.30 \\
$\mathbf{3}$ & 0.20 \\
$\mathbf{4}$ & 0.10 \\
\hline
\end{tabular}

The earthquake zones given in Table 3 are shown in Figure 4.

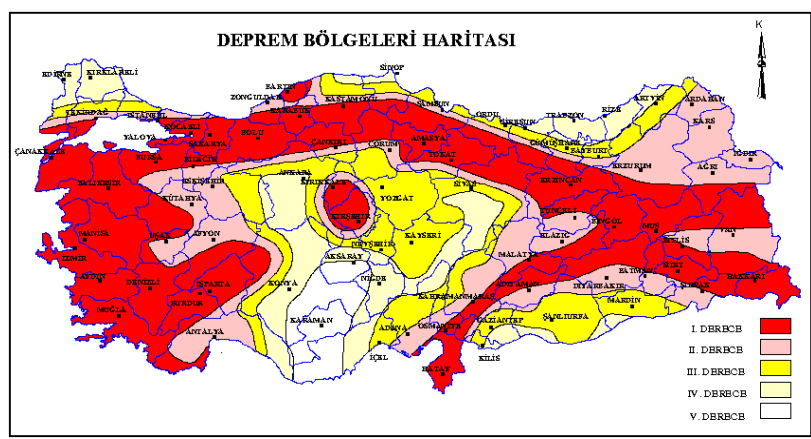

Figure 4. TSC-2007 earthquake zone map (Turkish Seismic Code (TSC-2007) (2007) Specifications for buildings to be built in seismic areas., 2007)

The total equivalent earthquake load affecting the building is calculated with Equation 5, Using the spectral acceleration coefficient obtained by Equation 4 .

$$
V_{t}=\frac{W A(T)}{R_{a}(T)} \geq 0.10 A_{0} I W
$$

Here, $\mathrm{Vt}, \mathrm{W}$ and $\mathrm{Ra}(\mathrm{T})$ denote the total equivalent earthquake load affecting the building, the weight of the earthquake-based structure and the earthquake load reduction coefficient, respectively.

The horizontal elastic design acceleration spectrum defined in the TSC-2018 regulation is given in Figure 5. 


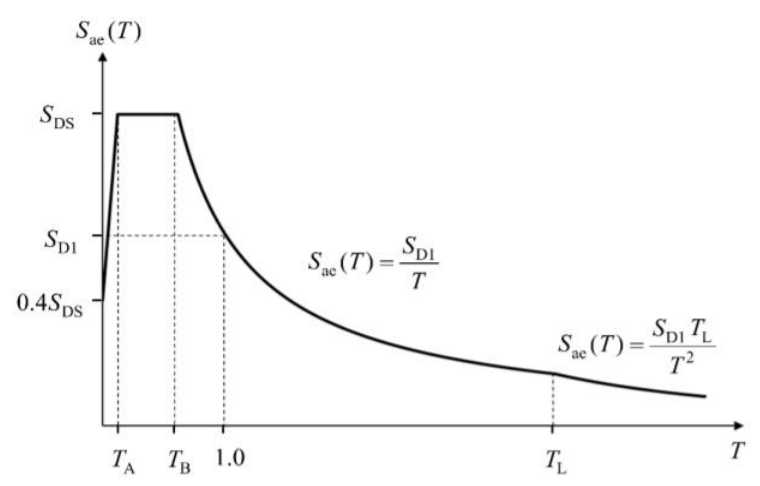

Figure 5. TSC-2018 horizontal elastic design acceleration spectrum (Turkish Seismic Code-2018 (TSC-2018), 2018)

The formulas given in Figure 5 to calculate the horizontal elastic design spectral acceleration in four different regions are defined in equations (6), (7), (8) and (9) respectively:

$$
\begin{array}{ll}
S_{a e}(T)=\left(0.4+0.6 \frac{T}{T_{A}}\right) S_{D S} & \left(0 \leq T \leq T_{A}\right) \\
S_{a e}(T)=S_{D S} & \left(T_{A} \leq T \leq T_{B}\right) \\
S_{a e}(T)=\frac{S_{D 1}}{T} & \left(T_{B} \leq T \leq T_{L}\right) \\
S_{a e}(T)=\frac{S_{D 1} T_{L}}{T^{2}} & \left(T \leq T_{L}\right)
\end{array}
$$

Here, $S_{a e}(T), T, T_{L}, S_{D S}, S_{D 1}, T_{A}$ and $T_{B}$ are respectively the horizontal elastic design spectral acceleration, the natural vibration period, the transition period to the constant displacement zone in the horizontal elastic design spectrum, the design spectral acceleration coefficient for the short period region, the period of 1.0 seconds. design spectral acceleration coefficient for the design, horizontal elastic design refer to the acceleration spectrum corner period.

The earthquake hazard map defined in TSC-2018 is given in Figure 6.

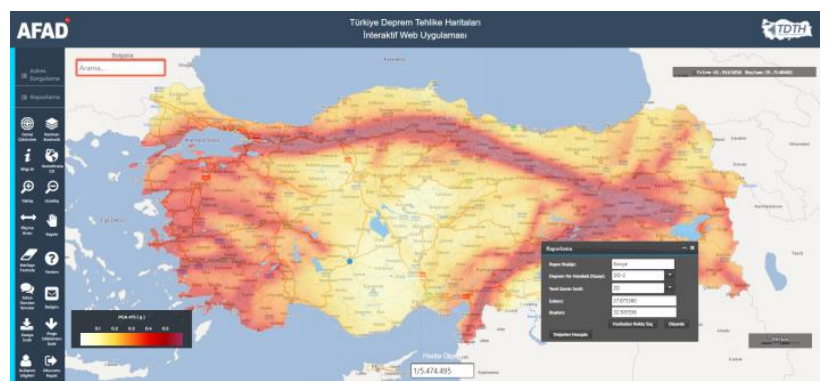

Figure 6. TSC-2018 eartquake hazard map (Turkish Seismic Code-2018 (TSC-2018), 2018) (10).

The total equivalent earthquake load that will affect the building is calculated with the formula

$$
V_{t E}=m_{t} S_{a R}(T) \geq 0.04 m_{t} I S_{D S} g
$$


Here, $V_{t E}, m_{t}, S_{a R}(T)$ and $g$ refer to the total equivalent earthquake load affecting the building, the structure weight based on earthquake, reduced design spectral acceleration and gravitational acceleration, respectively.

TSC-2007 and TSC-2018 codes have given some rules limiting the relative storey drift in order to prevent excessive displacements and the additional internal forces due to excessive drift that may occur in the structure during an earthquake.

In TSC-2007, the limitation of the relative floor displacements is calculated with the formulas (11), (12) and (13), taking into account the floor drifts given in Figure 7.

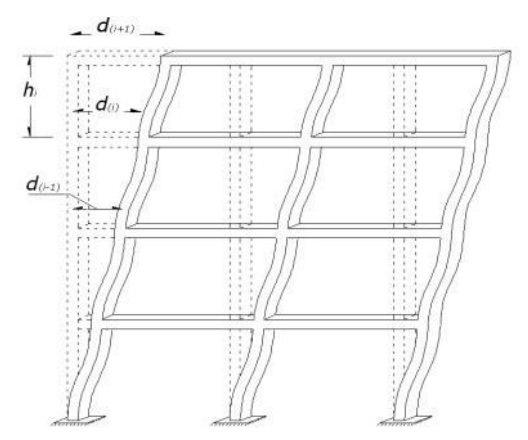

Figure 7. Relative story drift (Turkish Seismic Code (TSC-2007) (2007) Specifications for buildings to be built in seismic areas., 2007)

$$
\begin{aligned}
& \Delta_{i}=d_{i}-d_{(i-1)} \\
& \delta_{i}=R \Delta_{i} \\
& \left(\delta_{i}\right)_{\max } / h_{i} \leq 0.02
\end{aligned}
$$

Here, $d_{i}, \Delta_{i}, \delta_{i},\left(\delta_{i}\right)_{\max }$ ve $R$ refer to respectively the displacement calculated according to the reduced earthquake loads on the i'th floor of the building, the reduced relative storey displacement on the i'th floor of the building, the effective relative storey displacement on the i'th floor of the building, the maximum effective relative storey displacement on the $i$ 'th storey of the building, structural behavior coefficient. Limitation of relative floor offsets in TSC-2018 is calculated with the following formulas (14), (15) and (16).

$$
\begin{aligned}
& \Delta_{i}=u_{i}-u_{(i-1)} \\
& \delta_{i}=\frac{R}{I} \Delta_{i} \\
& \lambda \frac{\left(\delta_{i}\right)_{\max }}{h_{i}} \leq 0.008 \kappa
\end{aligned}
$$

Here, $\Delta_{i}, u_{i}, \delta_{i},\left(\delta_{i}\right)_{\max }, I, h_{i}, R, \lambda$ and $\kappa$ refer to respectively the reduced relative storey displacement expressing the difference in displacement between two consecutive floors for any column or shear wall, the reduced displacement on the i'th floor for the column or shear wall, the effective relative floor displacement for the column or shear wall on the Ith floor of the building, the highest value of the effective relative floor displacements on the i'th floor of the building, the building importance coefficient, the height of the i'th floor, the structural behavior coefficient, the empirical coefficient used in limiting the relative storey displacements and a coefficient used in limiting the relative storey displacements ( 1 for reinforced concrete buildings, 0.5 for steel buildings). 
Additional loads may occur in the structure as a result of the increase in the plastic deformations in the structural elements. These additional loads occur due to increasing the deformation and displacements in the structural elements as shown in Figure 8.
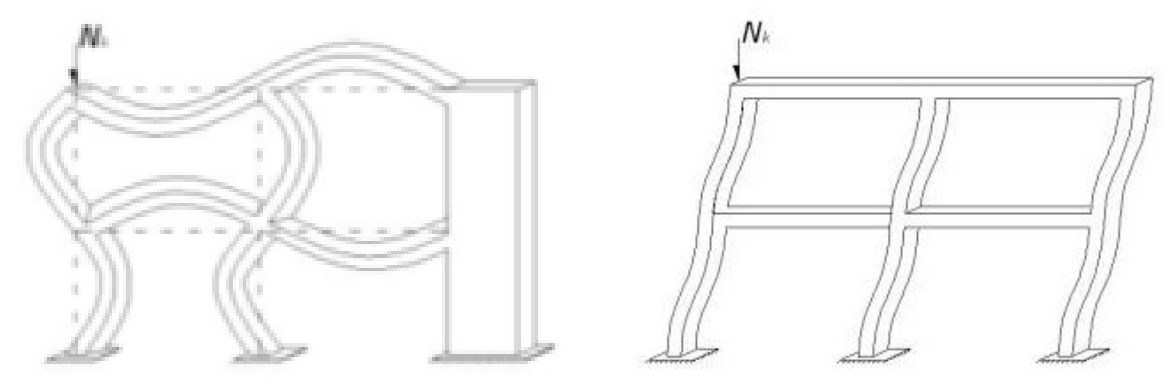

Figure 8. Second-order effects

The second order effects that may occur in the structure are limited in TSC-2007 and TSC-2018. The formula used to calculate second order effects in TSC-2007 is given in (17).

$$
\theta_{i}=\left(\Delta_{i}\right)_{o r t} \Sigma w_{i} / V_{i} h_{i} \leq 0.12
$$

Here, $\theta_{i},\left(\Delta_{i}\right)_{o r t}, V_{i}, w_{i}$ and $h_{i}$ refer to respectively, the second order effect indicator defined at i'th story of building, the average reduced relative floor displacement on the $i^{\prime}$ th floor of the building, the earthquake force acting on the i'th floor of the building, the weight of $i^{\prime}$ th story of building by considering live load participation factor, height of i'th story of building.

The formula used to calculate second-order effects in TSC-2018 is given in Formula (18).

$$
\theta_{I I, i}=\frac{\left(\Delta_{i}\right)_{o r t} \sum_{k=i}^{N} w_{k}}{V_{i} h_{i}} \leq 0.12 \frac{D}{C_{h} R}
$$

Here, $\theta_{I I, i},\left(\Delta_{i}\right)_{\text {ort }}, V_{i}, w_{k}, h_{i}, D, C_{h}, R$ refer to to respectively, the second order effect indicator defined at i'th story of building, average story of i'th story of building, story shear at i'th story of building in the earthquake direction considered, the total weight of building by considering live load participation factor, height of i'th story of building, overstrength coefficient, a coefficient defined depending on the nonlinear hysteretic behavior of the structural system

( 0.5 for reinforced concrete buildings, 1.0 for steel buildings), the structural behavior coefficient.

In the study, spectrum curves were obtained for both regulations specific to Konya province. In TSC-2007, the local soil class was taken as Z4. In TSC-2018, the closest soil class to this, the ZD class, was taken. Design spectrum curves obtained depending on local soil classes are given in Figure 9. 


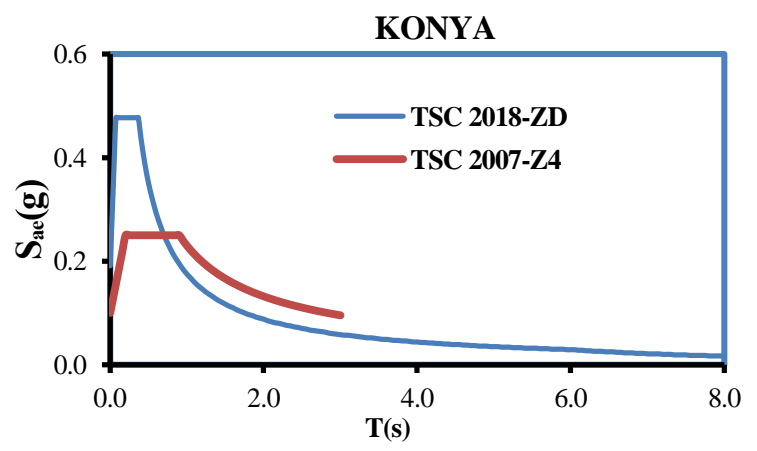

(a)

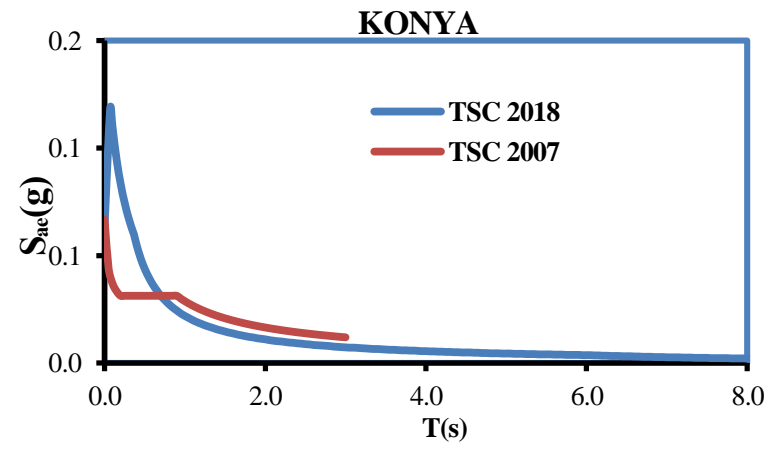

(b)

Figure 9. Spectrum curves, (a) design spectrum, (b) reduced design spectrum

\section{RESULTS AND DISCUSSIONS}

The mode deformations in the $1^{\text {st }}, 2^{\text {th }}$ and $3^{\text {rd }}$ modes obtained from the buildings as a result of the analysis are given in Figure 10. 


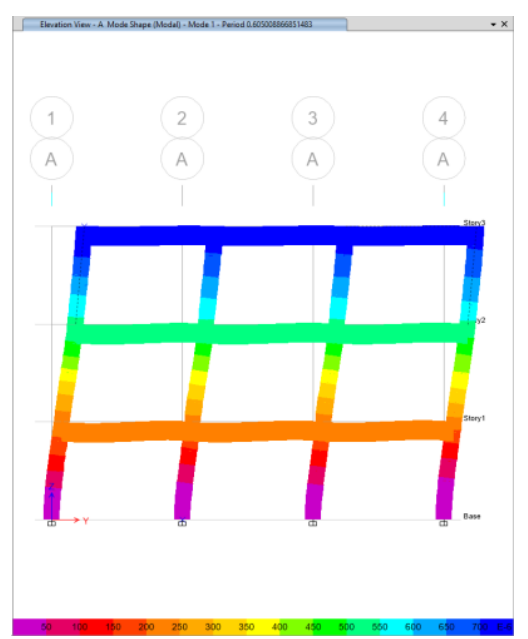

(a)

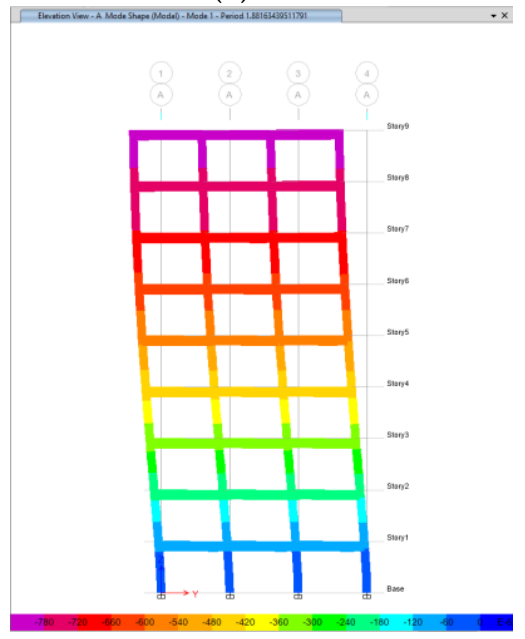

(d)

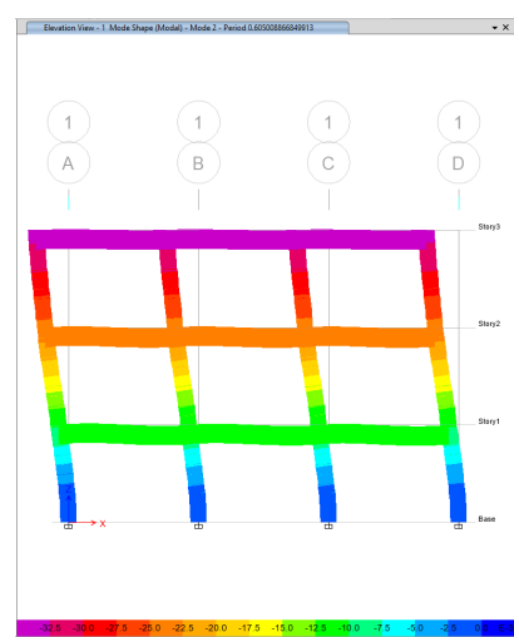

(b)

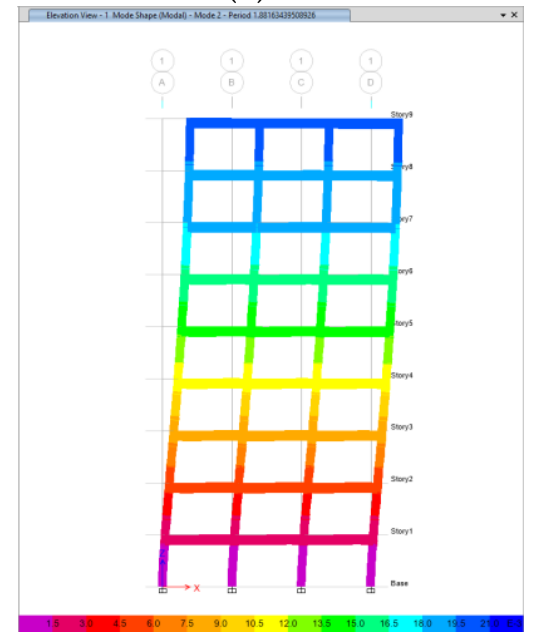

(e)

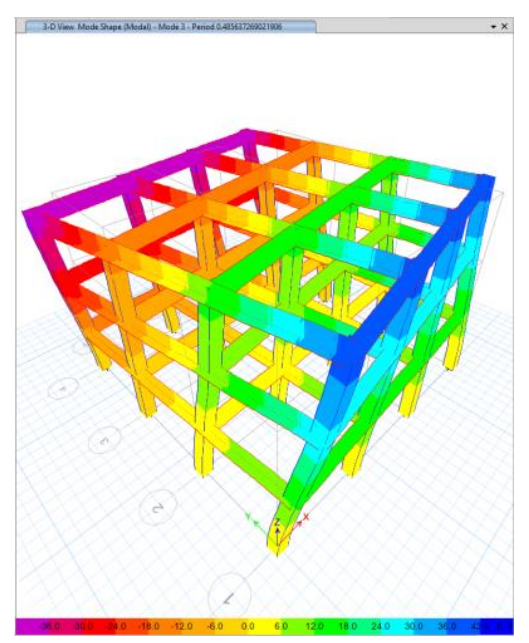

(c)

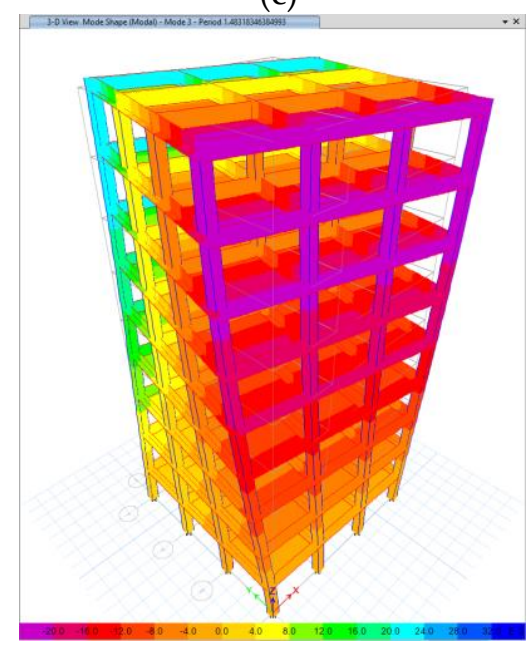

(f)

Figure 10. Mode deformations, (a) $1^{\text {st }}$ mode for 3-story building, (b) $2^{\text {th }}$ mode for 3-story building, (c) $3^{\text {rd }}$ mode for 3-story building, (d) $1^{\text {st }}$ mode for 9-story building, (e) $2^{\text {th }}$ mode for 9-story building, (c) $3^{\text {rd }}$ mode for 9-story building

The floor shear forces affecting the buildings are given in Figures 11 and 12. The floor shear forces were obtained from ETABS.

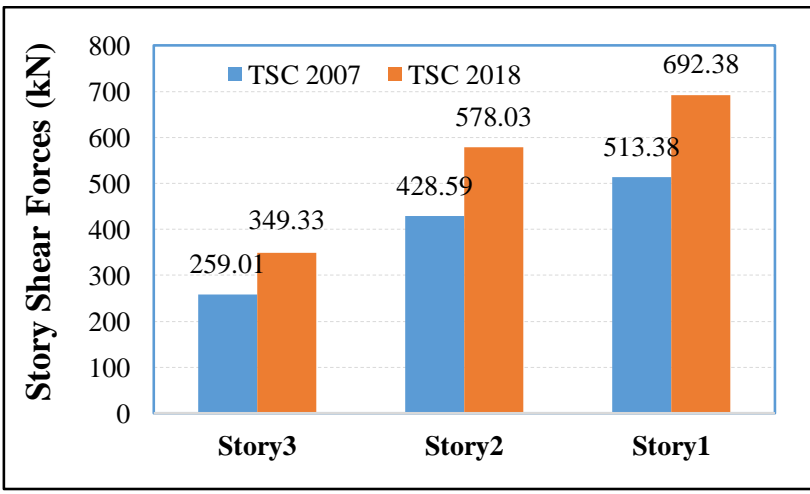

Figure 11. Floor shear forces for a 3-storey building 


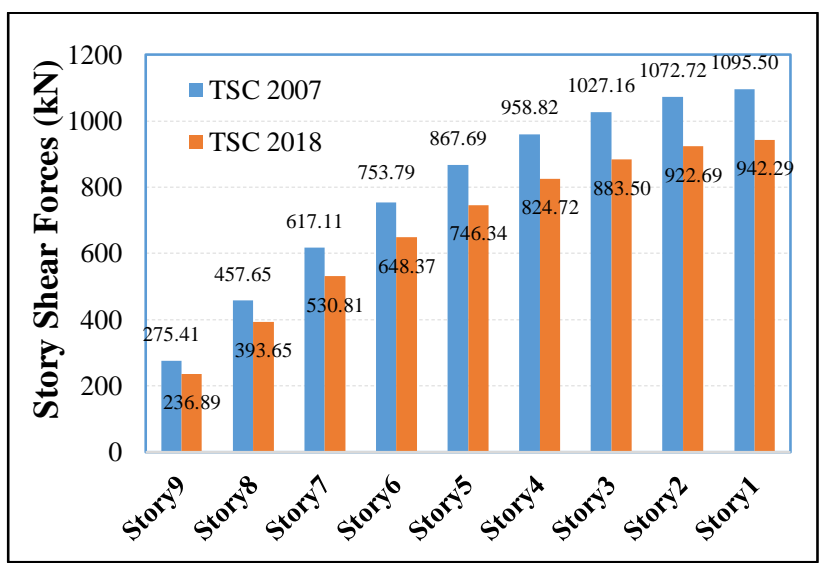

Figure 12. Floor shear forces for a 9-storey building

When the floor shear forces of the 3-storey building given in Figure 11 are examined, the results obtained from the TEC 207 code are higher, and when the floor shear forces of the 9-storey building in Figure 12 are examined, the results obtained from the TEC 2018 code are higher. Similar to the spetkrum curves obtained for the Konya region, if the natural vibration period of the building is greater than the soil characteristic periods, higher earthquake forces are obtained with the TEC 2007. On the other hand, if it is between the soil characteristic periods, higher earthquake forces are obtained with the TEC 2018.Floor displacements for a 3-storey and 9-storey building are given in Figure 13. 


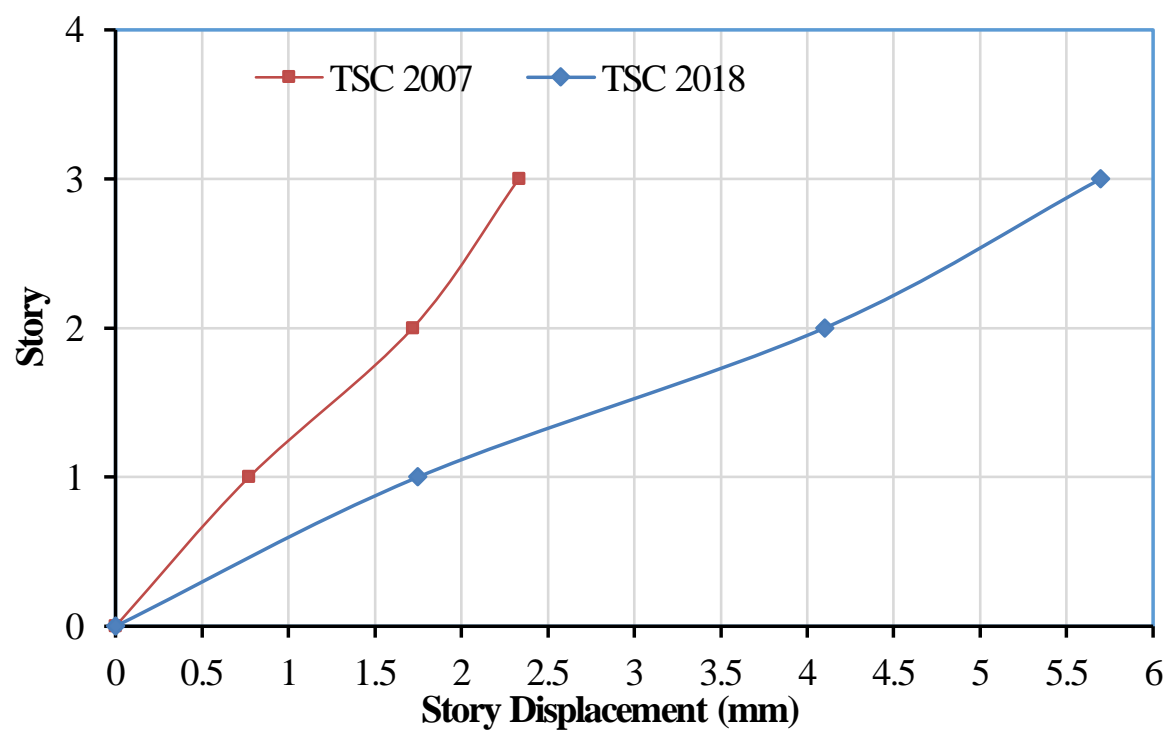

(a)

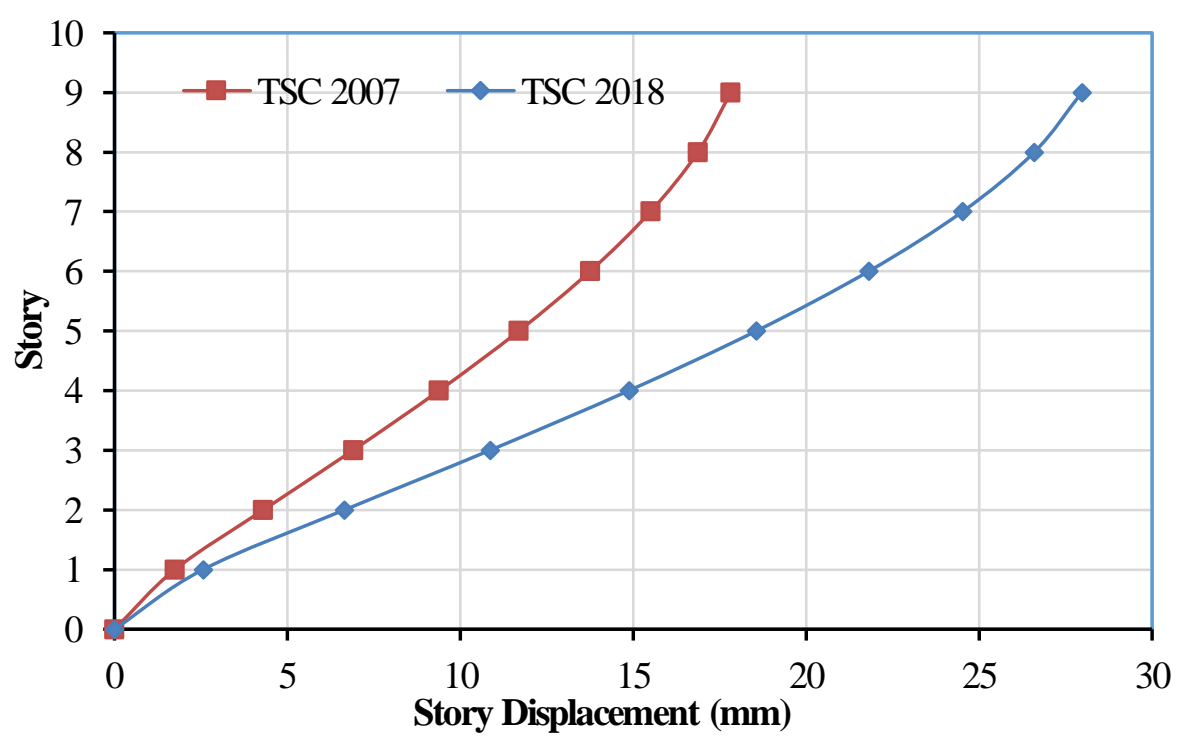

(b)

Figure 13. Floor displacements, (a)

3-storey building, (b) 9-storey building

In terms of floor displacements given in Figure 13, again high results were obtained in TSC-2018 regulation. The total equivalent earthquake load is 35\% less for a 3 -storey building and $16 \%$ less for a 9storey building compared to TSC-2018 in the values calculated with TSC-2007. The values obtained for the floor drift are given in Figure 14. 


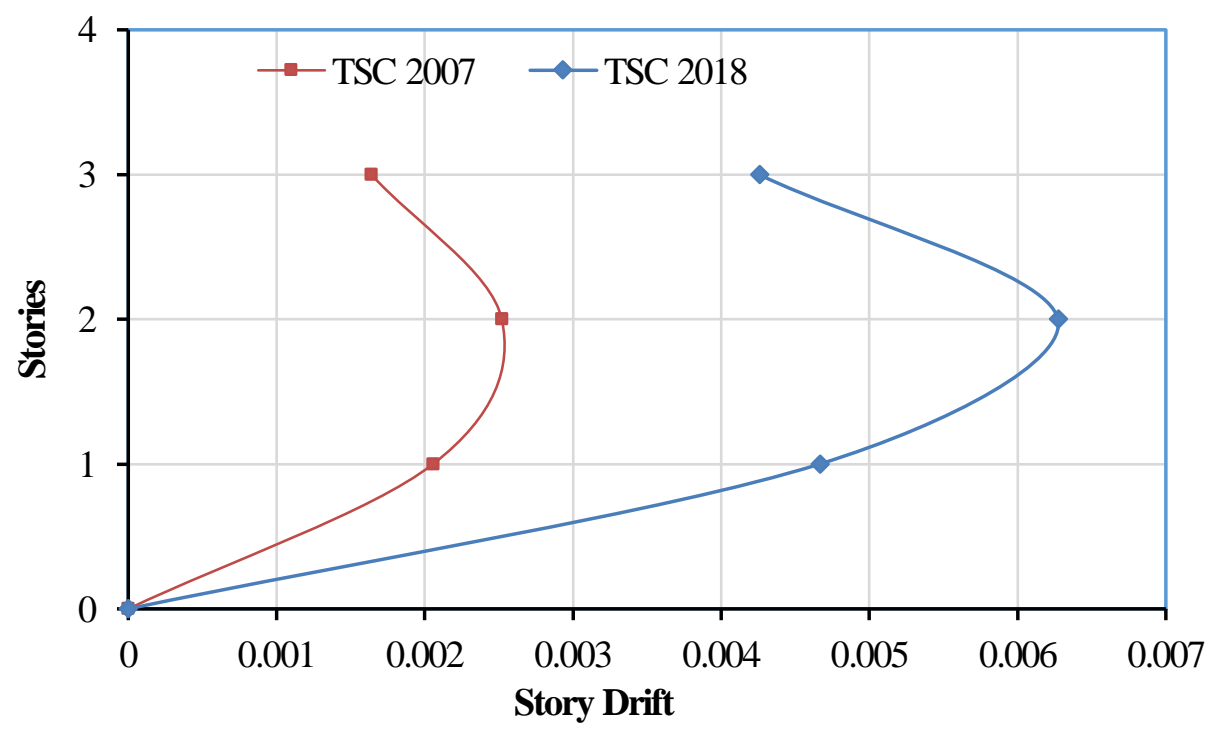

(a)

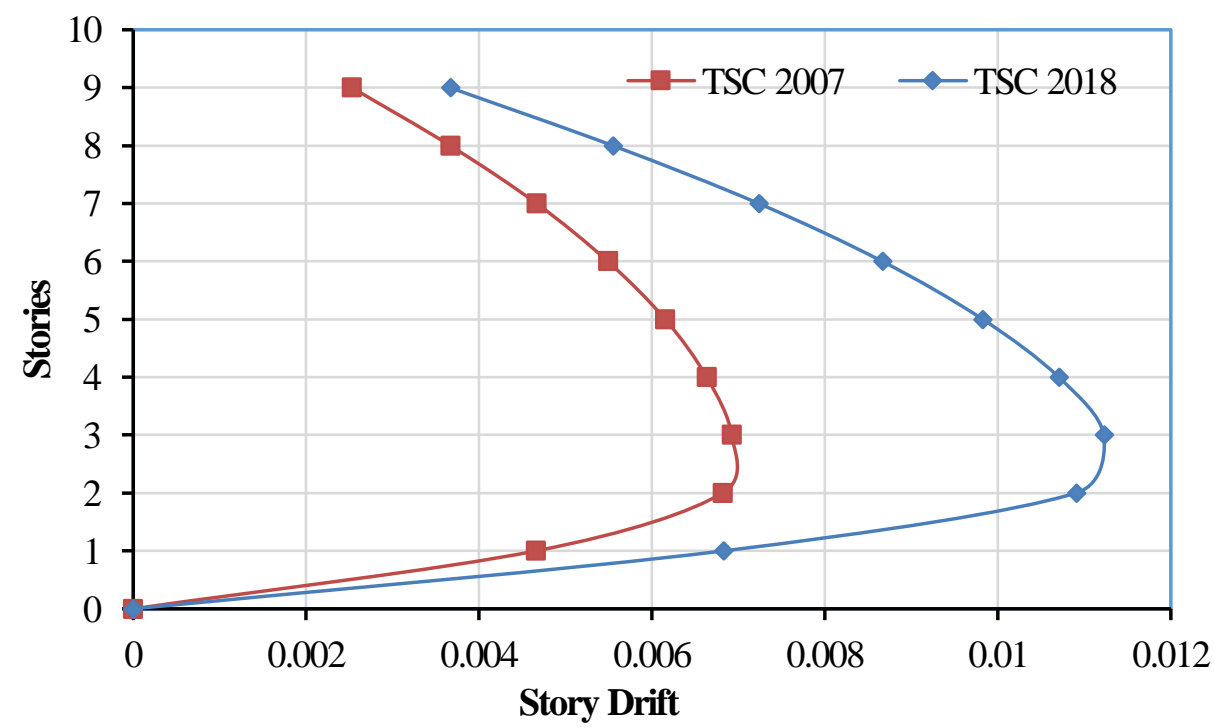

(b)

Figure 14. Floor displacement, (a) 3-storey building, (b) 9-storey building

In the calculations made to limit the second-order effects that may occur on buildings, it was observed that second-order effects did not occur on 3 and 9-storey buildings for TSC-2007 and TSC-2018 regulations. The results are given in Table 4 for a 3-story building and in Table 5 for a 9-story building. As seen in Table 4, the second-order effects were below the limit values for both codes. As seen in Table 5, the second-order effects were below the limit values for 9-storey buildings. 
Table 4. Limitation of second order effects for a 3-storey building, (a) TSC-2007, (b) TSC-2018

\begin{tabular}{|c|c|c|c|c|c|c|c|}
\hline Story & $\begin{array}{c}\mathrm{Hi} \\
(\mathrm{mm})\end{array}$ & $\begin{array}{l}\Delta \mathrm{i}(\text { ort }) \\
(\mathrm{mm})\end{array}$ & $\underset{(t)}{\sum W j}$ & $\begin{array}{l}V i \\
(t f)\end{array}$ & $\begin{array}{l}\text { vi*hi } \\
\text { (t.fm) }\end{array}$ & $\begin{array}{c}{ }^{\theta i}=\Delta \mathbf{i}(\text { ort }) * \sum W \mathbf{i} / \\
\text { vi*hi }\end{array}$ & ${ }^{\theta} \mathbf{i}<=0,12$ \\
\hline Story3 & 3000 & 0.614 & 552.6 & 25.9010 & 77703.21 & 0.004366569 & 0.004366569 \\
\hline Story 2 & 3000 & 0.946 & 1105.2 & 42.8586 & 128576.07 & 0.008131522 & 0.008131522 \\
\hline Story1 & 3000 & 0.772 & 1657.8 & 51.3375 & 154012.5 & 0.008309855 & 0.008309855 \\
\hline \multicolumn{8}{|c|}{ (a) } \\
\hline Story & $\begin{array}{c}\mathrm{Hi} \\
(\mathrm{mm})\end{array}$ & $\begin{array}{l}\Delta \mathrm{i} \text { (ort) } \\
(\mathrm{mm})\end{array}$ & $\underset{(t)}{\sum W j}$ & $\begin{array}{l}\mathrm{Vi} \\
(\mathrm{tf})\end{array}$ & $\begin{array}{l}\text { vi*hi } \\
\text { (t.fm) }\end{array}$ & 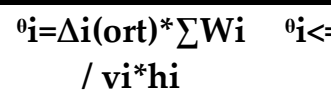 & $\mathrm{i}<=0,12 \mathrm{D} / \mathrm{C}_{\mathrm{h}} \mathrm{R}=0.09$ \\
\hline Story3 & 3000 & 1.597 & 552.6 & 34.93252 & 104797.56 & 0.00842102 & 0.008421019 \\
\hline Story2 & 3000 & 2.352 & 1105.2 & 57.8031 & 173409.3 & 0.01499014 & 0.014990144 \\
\hline Story1 & 3000 & 1.748 & 1657.8 & 69.23838 & 207715.14 & 0.013951 & 0.013951002 \\
\hline
\end{tabular}

(b)

Table 5. Limitation of second order effects for a 9-storey building, (a) TSC-2007, (b) TSC-2018

\begin{tabular}{|c|c|c|c|c|c|c|c|}
\hline Story & $\begin{array}{c}\mathrm{Hi} \\
(\mathrm{mm})\end{array}$ & $\begin{array}{l}\Delta \mathrm{i} \text { (ort) } \\
(\mathrm{mm})\end{array}$ & $\underset{(t)}{\sum W j}$ & $\begin{array}{l}\mathrm{Vi} \\
(\mathrm{tf})\end{array}$ & $\begin{array}{l}\text { vi*hi } \\
\text { (t.fm) }\end{array}$ & $\begin{array}{c}{ }^{\theta_{\mathbf{i}}=\Delta \mathbf{i}(\text { ort }) *} \sum \mathbf{W i} / \\
\mathbf{v i}^{*} \mathbf{h i}\end{array}$ & ${ }^{\theta} \mathbf{i}<=0,12$ \\
\hline Story9 & 3000 & 0.948 & 558 & 27.5407 & 82622.1 & 0.006402452 & 0.006402452 \\
\hline Story8 & 3000 & 1.376 & 1110.6 & 45.76494 & 137294.82 & 0.011130687 & 0.011130687 \\
\hline Story7 & 3000 & 1.747 & 1663.2 & 61.71115 & 185133.45 & 0.015694681 & 0.015694681 \\
\hline Story6 & 3000 & 2.059 & 2215.8 & 75.37933 & 226137.99 & 0.020174992 & 0.020174992 \\
\hline Story5 & 3000 & 2.305 & 2768.4 & 86.76948 & 260308.44 & 0.02451385 & 0.02451385 \\
\hline Story4 & 3000 & 2.487 & 3321 & 95.88159 & 287644.77 & 0.028713635 & 0.028713635 \\
\hline Story3 & 3000 & 2.594 & 3873.6 & 102.71568 & 308147.04 & 0.032608194 & 0.032608194 \\
\hline Story2 & 3000 & 2.557 & 4426.2 & 107.27174 & 321815.22 & 0.035168608 & 0.035168608 \\
\hline Story1 & 3000 & 1.745 & 4978.8 & 109.54977 & 328649.31 & 0.026435491 & 0.026435491 \\
\hline \multicolumn{8}{|c|}{ (a) } \\
\hline Story & $\begin{array}{c}\mathrm{Hi} \\
(\mathrm{mm})\end{array}$ & $\begin{array}{l}\Delta \mathrm{i} \text { (ort) } \\
(\mathrm{mm})\end{array}$ & $\sum W j(t)$ & $\begin{array}{l}\mathrm{Vi} \\
(\mathrm{tf})\end{array}$ & $\begin{array}{l}\text { vi*hi } \\
\text { (t.fm) }\end{array}$ & 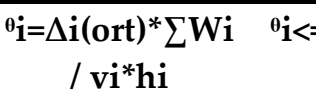 & $i<=0,12 \mathrm{D} / \mathrm{C}_{\mathrm{h}} \mathrm{R}=0.09$ \\
\hline Story9 & 3000 & 1.375 & 558 & 23.68903 & 71067.09 & 0.010796136 & 0.010796136 \\
\hline Story8 & 3000 & 2.08 & 1110.6 & 39.36453 & 118093.59 & 0.019561163 & 0.019561163 \\
\hline Story7 & 3000 & 2.712 & 1663.2 & 53.0806 & 159241.8 & 0.028325467 & 0.028325467 \\
\hline Story6 & 3000 & 3.248 & 2215.8 & 64.83723 & 194511.69 & 0.036999927 & 0.036999927 \\
\hline Story5 & 3000 & 3.684 & 2768.4 & 74.63442 & 223903.26 & 0.045549965 & 0.045549965 \\
\hline Story4 & 3000 & 4.015 & 3321 & 82.47218 & 247416.54 & 0.053892173 & 0.053892173 \\
\hline Story3 & 3000 & 4.208 & 3873.6 & 88.35049 & 265051.47 & 0.0614979 & 0.0614979 \\
\hline Story2 & 3000 & 4.088 & 4426.2 & 92.26937 & 276808.11 & 0.065367686 & 0.065367686 \\
\hline Story1 & 3000 & 2.559 & 4978.8 & 94.22881 & 282686.43 & 0.045070254 & 0.045070254 \\
\hline
\end{tabular}

(b) 


\section{CONCLUSIONS}

Turkey in January-2019 history of the most important changes made with the entering into force of the abolition of the concept of the TSC-2018 earthquake. instead,Turkey Earthquake Hazard Map is modified based on the spectral information depending on the location of the structure. Besides, while the statistical parameters for the standard design earthquake ground motion in the TSC-2007 earthquake code are preserved, three additional earthquake levels have been added for special structures.

- In the base shear forces obtained from the current and old earthquake regulations, if the building period is between the ground dominant periods, higher values were obtained in TSC-2018, if greater than TB, in TSC-2007.

- When storey displacements and relative storey displacements are compared, more unfavorable results were obtained in design according to TSC-2007 regulation, due to the effective section stiffness coefficient required to be used in the analysis of linear calculation methods in the TSC-2018 regulation. - The second-order effects obtained after the analysis of the 3 and 9-storey buildings were below the limit values according to both regulations.

- In the TCS 2018 regulation, since the concept of earthquake zone is removed, map-based spectral acceleration values are calculated according to the distance of the coordinates to the fault.

- According to the reduced design graph, in TSC 2018, the elastic spectral acceleration value is at the maximum level in $\mathrm{T}=\mathrm{TB}$ period. In TSC 2007, it is obtained at $\mathrm{T}=\mathrm{T} 0$.

\section{REFERENCES}

Balun, B., Nemutlu, O. F., \& Sari, A., 2020, "Investigation Of The Effect of TEC 2018 Simplified Design Rules On Base Shear Force" Turkish Journal of Nature and Science, 9, 173-181. https://doi.org/10.46810/tdfd.749257

Basaran, V., 2018, "Evaluation of Seismic Loads for Afyonkarahisar According to Turkish Seismic Code (TSC2019)", Afyon Kocatepe University Journal of Sciences and Engineering, 18(3), 1028-1035. https://doi.org/10.5578/fmbd.67739

Demir, A., \& Donmez, D., 2008, "The Factors Affecting Torsional Irregularity in Multi-Storey Structures", Celal Bayar University Journal of Science, 4, 31-36.

Dogangun, A., \& Livaoglu, R.,2006, "Comparison of Seismic Analysis Methods for Multistory Buildings", First European Conference on Earthquake Engineering and Seismology, (1314), 1-10. Geneva, Switzerland.

ETABS, 2020, "Integrated Software for Structural Analysis \&Design", Computers and Structures Inc.

Humar, J., \& Mahgoub, M. A., 2003, "Determination of seismic design forces by equivalent static load method", Canadian Journal of Civil Engineering, 30(2), 287-307. https://doi.org/10.1139/102-067

Keskin, E., \& Bozdogan, K. B., 2018, "Evaluation of 2007 And 2018 Turkish earthquake code For The Province of Kırklareli", Kırklareli University Journal of Engineering and Science, 4(1), 74-90.

Kumbasaroglu, A., \& Celik, A., 2019, "Assessment of Seismic Performance Level of a Historical Masonry Structure Using Equivalent Seismic Load Method", Erzincan University Journal of Science and Technology, 12(3), 1590-1600. https://doi.org/10.18185/erzifbed.619692

Ozer, O., \& Yuksel, S. B., 2020, "Comparing Analysis Results Of Tall Buildings Which Takes Earthquake Effects By Reinforced Concrete Frames And Shear Walls Together According To TBEC 2018 And TEC 2007", Nigde Omer Halisdemir University Journal of Engineering Sciences, 9(2), 931-945. https://doi.org/10.28948/ngmuh.694781

Song, J., Gao, Y., Feng, T., \& Xu, G., 2018, "Effect of site condition below slip surface on prediction of equivalent seismic loading parameters and sliding displacement", Engineering Geology, 242, 169183. https://doi.org/10.1016/j.enggeo.2018.05.003

Tezcan, S. S., \& Alhan, C., 2001, "Parametric analysis of irregular structures under seismic loading according to the new Turkish Earthquake Code", Engineering Structures, 23, 600-609. 
https://doi.org/10.1016/S0141-0296(00)00084-5

Turkish Seismic Code-2018 (TSC-2018), 2018, Ankara, Turkey: Disaster and Emergency Management.

Turkish Seismic Code (TSC-2007), 2007, "Specifications for buildings to be built in seismic areas", Ankara, Turkey: Ministry of Public Works and Settlement.

Ucar, T., \& Merter, O., 2009, "Effect of Configuration of Shear Walls at Floor Plan to Earthquake Behavior of Shear Wall-Frame Reinforced Concrete Buildings", Dokuz Eylül University Engineering Faculty Journal of Science and Engineering, 11(2), 11-18. 